\title{
Sectoral innovation system foresight in practice: Nordic facilities management foresight
}

\author{
Andersen, Per Dannemand; Dahl Andersen, Allan ; Jensen, Per Anker; Rasmussen, Birgitte
}

\section{Published in:}

Futures The journal of policy, planning and futures studies

Link to article, DOI:

10.1016/j.futures.2014.04.012

Publication date:

2014

Link back to DTU Orbit

Citation (APA):

Andersen, P. D., Dahl Andersen, A., Jensen, P. A., \& Rasmussen, B. (2014). Sectoral innovation system foresight in practice: Nordic facilities management foresight. Futures The journal of policy, planning and futures studies, 61, 33-44. https://doi.org/10.1016/j.futures.2014.04.012

\section{General rights}

Copyright and moral rights for the publications made accessible in the public portal are retained by the authors and/or other copyright owners and it is a condition of accessing publications that users recognise and abide by the legal requirements associated with these rights.

- Users may download and print one copy of any publication from the public portal for the purpose of private study or research.

- You may not further distribute the material or use it for any profit-making activity or commercial gain

- You may freely distribute the URL identifying the publication in the public portal 


\section{Accepted Manuscript}

Title: Sectoral innovation system foresight in practice: Nordic facilities management foresight

Author: Per Dannemand Andersen Allan Dahl Andersen Per Anker Jensen Birgitte Rasmussen

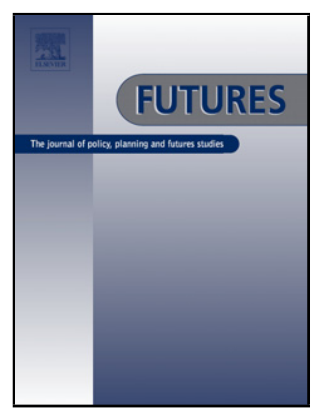

PII: S0016-3287(14)00074-3

DOI: http://dx.doi.org/doi:10.1016/j.futures.2014.04.012

Reference: JFTR 1925

To appear in:

Received date: 20-9-2013

Revised date: 21-4-2014

Accepted date: $\quad$ 22-4-2014

Please cite this article as: P.D. Andersen, A.D. Andersen, P.A. Jensen, B. Rasmussen, Sectoral innovation system foresight in practice: Nordic facilities management foresight, Futures (2014), http://dx.doi.org/10.1016/j.futures.2014.04.012

This is a PDF file of an unedited manuscript that has been accepted for publication. As a service to our customers we are providing this early version of the manuscript. The manuscript will undergo copyediting, typesetting, and review of the resulting proof before it is published in its final form. Please note that during the production process errors may be discovered which could affect the content, and all legal disclaimers that apply to the journal pertain. 


\section{Per Dannemand Andersen*}

Technical University of Denmark, Department of Management Engineering, Produktionstorvet 424, DK-2800 Kgs. Lyngby, Denmark

E-mail: pean@dtu.dk

* Corresponding author

Allan Dahl Andersen

Oslo University, Centre for Technology, Innovation and Culture (TIK),

Postboks 1108 Blindern, N-0317 Oslo, Norway

Per Anker Jensen

Technical University of Denmark, Department of Management Engineering, Produktionstorvet 424, DK-2800 Kgs. Lyngby, Denmark

Birgitte Rasmussen

Technical University of Denmark, Department of Management Engineering, Produktionstorvet 424, DK-2800 Kgs. Lyngby, Denmark

*Title Page with Author Information 


\title{
Sectoral innovation system foresight in practice: Nordic facilities management foresight
}

\section{Highlights}

- We contribute to the theoretical underpinning and theory building in foresight

- We investigate how elements of innovation system theory can contribute to foresight

- We focus on foresight in industrial sectors as a domain overlapping public and corporate settings

- External megatrends and internal trends and challenges for the Nordic facilities management sector

Priority setting for longer term research in a cross national (Nordic) setting

\begin{abstract}
A number of studies have explored the interconnection between the foresight literature and the innovation system literature. This paper adds to these studies by investigating how theoretical elements of the innovation system approach can contribute to the design and practice of foresight processes. The paper originates in a foresight project in the Nordic facilities management sector. The goal of the foresight project was to identify the possible futures of the facilities management sector in the Nordic countries (Denmark, Finland, Norway, and Sweden) and, based on the findings, to establish a proposal for a common Nordic facilities management research agenda. The paper finds that three elements of the innovation system literature are of particular interest for the practice of foresight: innovation systems and context dependency, learning and user-producer interactions, and the role of knowledge and knowledge production. These elements are embedded into a simple sectoral innovation system model (including actors, knowledge flows, and the strategic environment).
\end{abstract}

Keywords: Foresight; sectoral innovation system; facilities management; priority setting of research; Nordic.

\section{Introduction}

A wealth of literature exists on approaches to foresight in both public policy making [1]-[3] and corporate foresight [4]-[6], including proposals on how to design foresight exercises in public and corporate settings. However, foresight in industrial sectors often lies on the border between public policy and corporate strategy. In these cases, the focus is not on strategic issues for individual firms or on firms' strategic business units but rather, on whole industrial sectors. Sponsors and target groups for sector foresight exercises can include both policy makers and industrial associations, but individual firms might also benefit from both the processes and the results of such exercises. A series of 
nine sectoral innovation foresight exercises have been conducted by EuropeInnova/Sectoral Innovation Watch on behalf of the European Commission in sectors such as aeronautics and space, automotive, construction, and food and beverage [7]-[9]. Another example is the Brazilian Centre for Strategic Studies and Management (CGEE), which on behalf of the Brazilian Agency for Industrial Development (ABDI) has conducted foresight studies in industrial sectors such as medical equipment, furniture, textiles and aeronautics.

The focus of this paper is a foresight project in the Nordic facilities management industry whose goal was to identify the possible futures of the facilities management sectors in the Nordic countries (Denmark, Finland, Norway, and Sweden) and, based on its findings, to establish a proposal for a common Nordic research agenda. Thus, the project concerned priority setting in longer-term research activities. This priority setting in $\mathrm{R} \& \mathrm{D}$ is both an issue in innovation management and one of the traditional rationales for foresight [10].

The practical question raised from this is: Which theoretical framework can underpin the design of such an R\&D priority-setting, cross-national foresight exercise for an industrial sector such as the Nordic facilities management sector?

Most academic foresight literature is descriptive or normative and relates to the practice of foresight [11]. It is generally acknowledged in the literature that there is a gap between practice and theory in foresight [7], [12], [13], and thus, the 'theoretical underpinnings' of foresight and theory building in foresight have become recent research focuses [7], [14], [15]. It is suggested that the theoretical underpinnings of foresight, as well as foresight studies, draw or should draw from a variety of established academic disciplines, such as management, computer sciences, cultural anthropology, economics, history, industrial engineering (decision sciences), mathematics, philosophy and ethics, political science, psychology, public administration, social psychology, sociology, statistics, systems theory, etc. [15]. Searching for a theoretical framework for designing a practical foresight project can be an immense exercise. To narrow the search, we adopt the perspective of some earlier studies that the theoretical rationale for policy-oriented foresight exercises is supported by the perspective of evolutionary economics and the innovation systems approach [16]. However, it has also been argued that, "At present a gap can be perceived between innovation theory and foresight practice, i.e., there is no specific framework available that would combine both" [7].

In general, there is very little communication between innovation systems research and foresight, and the linkages between them remain embryonic and underdeveloped [17]. The interconnection between the foresight and the innovation systems literature has been explored by a small number of studies [18]-[21]. However, these studies mainly focus on how foresight can contribute to innovation systems analysis and innovation policy making; they do not investigate how the innovation systems framework can contribute to the practice of foresight.

A systems approach to foresight is not completely novel; an explicit systems approach to foresight was already suggested by Saritas [22]. However, the work of Saritas, although profound, is mainly about complex systems in general, and as such, it is not focused on innovation or on the innovation systems framework.

Furthermore, a review of the literature on foresight and futures studies within facilities management reveals very limited (if any) use of contributions from the innovation systems literature [23]-[27]. One exception might be a Finnish study on foresight in the more broadly defined services sector [28]. In particular, the facilities 
management foresight and futures reports developed by interest groups, firms, consultancies and public authorities present no theoretical or conceptual contributions from the innovation systems approach [29]-[33].

Hence, the research question raised from this state of research is the following: How can elements from the innovation system framework contribute to the practice of sector foresight?

Using the innovation systems framework as a theoretical underpinning for foresight can be understood as further embracing already ongoing trends within foresight. First, the foresight literature has been increasingly recognising that foresight is highly context dependent and that those context specificities must be accounted for [22], [34], [35]. Despite its importance, however, this work is currently limited [36]. Second, foresight exercises most often do not take sufficient notice of the demand for knowledge or existing competences, and the realities and wishes of firms are not adequately emphasised [17].

The structure of this paper is as follows. Following this introduction, Section 2 analyses how core elements of the innovation systems framework contribute to the design of an R\&D, priority-setting, cross-national, sector foresight exercise. Because facilities management has only recently been conceptualised and it is not commonly known, Section 3 contains a brief introduction to this sector. To guide the reader's considerations of possible generalisations from the study's findings outside of its empirical focus, this section also includes a short paragraph on how the Nordic facilities management market and sector differ from the international market. The structure and characteristics of the sector presented in Section 3 were used in the foresight process to structure the mapping and to guide the development of the participatory elements (workshops and questionnaire). Section 4 presents the Nordic facilities management foresight project and its processes, and Section 5 presents the results of each element of the foresight process. Finally, Section 6 presents the conclusions of the study and its additional perspectives.

\section{Contributions from the innovation systems approach}

In the following, we briefly analyse how core elements of the innovation systems framework contribute to the design of an R\&D priority-setting, cross-national, sector foresight exercise. The section draws on a more comprehensive conceptual analysis of innovation systems foresight [37].

\subsection{Innovation systems and context dependency}

The innovation systems approach first emerged as a national innovation system that was concerned with building a national knowledge infrastructure for economic development [38]-[40]. The framework has developed in different directions that include different levels and dimensions, such as regional [41], [42], sectoral [43], [44] and technology-specific innovation systems [45], [46]. In parallel, the practice of foresight has included national, regional, sectoral, and technology foresight, thus reflecting that an innovation system may be delimited nationally/territorially, sectorally, or according to the technology or knowledge base. These determinants of limits are mutually complementary and may be applied individually or in combination based on the object of the research.

The flexibility in defining the levels and boundaries for innovation systems comes from viewing the economy as an evolving, complex, and open system, i.e., a recursive system [47]. This recursiveness indicates that innovation systems interact and are 
mutually interdependent and that every system is embedded in a broader social system. The different approaches reflect the diversity of innovation dynamics that we can observe in the real world. Innovation dynamics differ across contexts [48]. Moreover, institutions relating to patents, appropriability conditions, competition and market structure differ in importance across nations and industrial sectors [38], [49]. These insights suggest that innovation is a context-dependent phenomenon and that 'unnecessary' aggregations and generalisations must be avoided. This is in accordance with recent developments in the foresight literature, in which it is increasingly recognised that foresight is highly context dependent and that context specificities must be accounted for [22], [34], [35].

This realisation has two implications for the design of a sectoral, cross-national foresight exercise. First, a sectoral innovation system cannot always be analysed independent of its national or territorial context. Although we eventually want to create a result that is aggregated across four countries, we need to design the foresight process so that differences in national contexts can be examined. For example, trends in the cost of oil belong in a genuine international context, whereas trends in the outsourcing of public facilities management services belong in national contexts. Second, this naturally suggests that we must distinguish between the foresight exercise's focus area, in this case the facilities management sector, and its context. We must distinguish between future (mega) trends in the external environments (context) of the facilities management sector and trends and challenges within the sector.

\subsection{Learning and user-producer interactions}

Another core element in the innovation systems framework is that the most central activity in an innovation system is learning, and learning is mainly interactive [50]. Nooteboom argues that as competition, specialisation, and, in turn, complexity increase, the value of firm-external knowledge increases, which makes interactive learning the most important type of learning [51]. The explicit introduction of interactive learning to innovation studies came in the form of user-producer interactions [52]. Lundvall argues that innovation emerges from confronting user needs with technological opportunities.

This has implications for the design of a sectoral, cross-national foresight exercise. In defining the sector, its upstream and downstream value chains must be considered. However, an overly complex description of a sector will require a more time-consuming analysis and blur the participatory parts of the foresight projects.

\subsection{The role of knowledge and knowledge production}

The innovation systems approach focuses on the flow of information and knowledge between actors, in contrast to other analytical approaches that focus on the flow of money or goods. As stated by Freeman, "Numerous case studies of innovation brought out the importance of flows of information and knowledge between firms as well as within firms. Moreover, the results of the empirical research pointed to the importance both of flows to and from sources of scientific and technical knowledge and of flows to and from users of products and processes" [53]. Again, the importance of learning from the user-producer interaction is emphasised. This also includes the interactions of the knowledge producers and users.

This approach has two implications for the design of a sectoral, cross-national foresight exercise. First, future knowledge and competence needs must be included in the foresight project, which is not surprising given that the overall aim of this project is to 
establish a Nordic research agenda. Second, the flow of knowledge between a sector's knowledge producers (often simplified to research and teaching) and knowledge users must be included in the process. Extending the breadth of knowledge in relation to the future is a common rationale for foresight projects [11], and knowledge has an important role in many models of foresight studies [54]. However, as observed by Smits, Kuhlmann and Shapira: "Foresight most often does not take sufficient notice of the demand for knowledge, existing competences, and the reality and wishes of firms are not emphasized" [17].

\section{Facilities management and the facilities management sector}

A European standard from 2008 defined facilities management as "the integration of processes within an organization to maintain and develop the services which support and improve the effectiveness of its primary activities" [55].

\subsection{Facilities management services, providers, and customers}

The scope of facilities management is often grouped around demands that are summarised under two main headings: 'Space \& Infrastructure (S\&I)' and 'People \& Organisation (P\&O)' [55]. See table 1. A European standard for facilities management taxonomy introduces the term standardised facility products, which are generic facility services that can be compared across organisations and borders.

Table 1 Standardised facilities management services [56]

\begin{tabular}{ll} 
Space \& Infrastructure (S\&I) & People \& Organisation (P\&O) \\
\hline Space & Health, safety and security \\
Outdoors & Hospitality \\
Cleaning & ICT \\
Workplace & Logistics \\
Industry sector specific & Business support (Management support) \\
\hline
\end{tabular}

A facilities management service provider can be internal or external to the customer. Among the large international providers of facility management are G4S, which has 630,000 employees and is the world's largest employer after Wal-Mart; ISS, with more than 520,000 employees; and Johnson Controls Facility Management. Both G4S and ISS have their roots in Denmark in the beginning of the 20th century. Facilities management customers can be international companies of various sizes, such as IBM or Nokia, or public institutions (e.g., municipal institutions or overseas military bases). No figures for the global facilities management market are publicly available, but the volume of the European facilities management market was estimated to be approximately 655 billion $€$ in 2008 [57].

A Danish survey analysed the typology of the facilities management market [58] and identified four main groups of clients (or customers) and ten provider industry branches. See table 2 . 
Table 2 Facilities management customers and providers [58]

\begin{tabular}{|c|c|}
\hline Customers & Providers \\
\hline Industry & - Construction and civil engineering \\
\hline - $\quad$ National firms & - Catering \\
\hline - International firms & - $\quad$ Real estate and renting \\
\hline Private service & - Finance and insurance \\
\hline - $\quad$ Trade and operational service & - IT consultancies \\
\hline $\begin{array}{l}\text { - Finance, IT and knowledge } \\
\text { service }\end{array}$ & $\begin{array}{l}\text { - Travelling agencies, cleaning and other } \\
\text { operational service }\end{array}$ \\
\hline Public service & $-\quad$ Waste \\
\hline - $\quad$ Municipalities & - Machinery and electrical equipment repair work \\
\hline$-\quad$ Regions & - Transportation \\
\hline$-\quad$ State & - Knowledge services \\
\hline Housing associations & \\
\hline
\end{tabular}

\subsection{The market for facilities management services in the Nordic countries}

In general, the facilities management sector has a strong international orientation, partly because of globalisation and partly because many multinational companies are among both the sector's providers and its customers. However, the Nordic facilities management market differs in five areas from the international markets. First, the public sector is an important player in all of the Nordic countries, whereas internationally, facilities management is primarily developed in the private sector. However, the degree of outsourcing of facilities management services from public clients to private providers varies among the four Nordic countries. Second, facilities management in the Nordic countries is very much influenced by people with professional backgrounds, such as architects and engineers, and, consequently, the construction aspects of property management are a major focus of facilities management services. Third, the climatic conditions in the Nordic countries place major demands on the design and management of buildings, and thus energy and environmental conditions are much emphasised. Fourth, an important focus in the Nordic countries is considerations such as daylight in buildings and ergonomic workplace design. Additionally, staff and user involvement play an important role in the Nordic facilities management sector and are considered important issues in attempts to generalise findings outside of the Nordic region.

A Delphi survey involving experts from the Nordic facilities management sector concluded that the total actual market for facilities management services in the Nordic countries amounted to 26 billion $€$ in 2010 [59].

\section{The Nordic facilities management foresight project}

The Nordic facilities management foresight project was initiated in 2010. The project followed a generic foresight process [58] that was adapted to the actual case. The process had three phases, each of which contained sub-phases (see Fig. 1). The planning phase comprised preparation and organisation of the foresight exercise. The main phase was the most comprehensive, as well as the most time-consuming and labour-intensive part of the 
foresight process. It is in this phase that sustainable knowledge, visions and future possibilities were developed and priorities set among the formulated possibilities on the basis of well-described criteria. The main phase was divided into four sub-phases: mapping, foresighting, prioritising and planning. The follow-up phase comprised two sub-phases: dissemination and learning.

Figure 1 A generic foresight process adapted to the facilities management (FM) case [60].

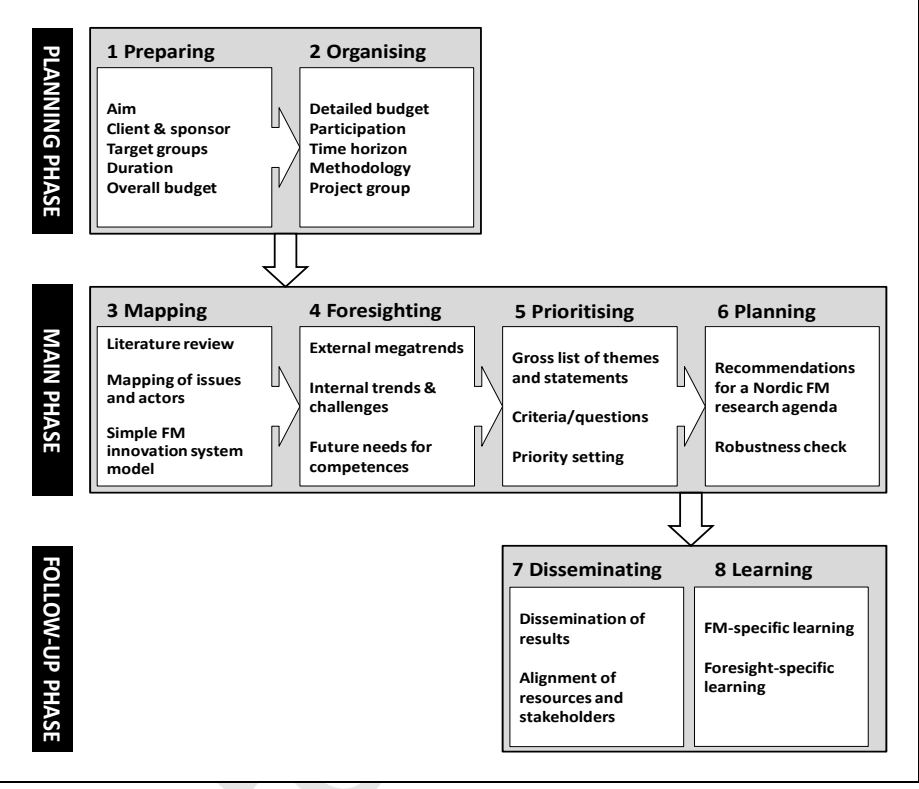

\subsection{Preparing and organising}

The aim of the foresight project was to identify future possibilities for the facilities management sector in the Nordic countries and, based on the findings, to establish a proposal for a common Nordic research agenda. The client was the Danish Centre for Facilities Management at the Technical University of Denmark. This centre is sponsored by the RealDania foundation, a philanthropic association that supports projects in the built environment within three focus areas: cities, buildings and built heritage. The target groups of the foresight project were the facilities management research communities and facilities management practitioners in the Nordic countries. The duration of the project was approximately two years, with the iterative activities (sub-phases 4, 5, 6) occurring from October 2010 to August 2011. The overall budget was DKK 500,000 (approximately EUR 67,000), most of which was used for wages and travel costs for the project team. Other workshop participants' expenditures were not included in the project budget.

Participation in the process was closed in the sense that only invited persons could participate in the workshops and surveys. The project's prospective parts had two time 
horizons: a short term ( 2 to 5 years) and a long term (10 to 15 years). The applied methodology included the main methods: literature review, expert workshops, megatrend analysis and a Delphi-like questionnaire. A project group of two foresight experts assisted by a facilities management expert - three of the authors of this paperadministered and conducted the project.

\subsection{Mapping}

The mapping sub-phase entailed a review of the vast literature on the future of facilities management and on the strategic environment of the facilities management sector. The latter comprised mostly literature, with no specific reference to the sector. The relevant references belonged to two groups: 1) the traditional academic literature of books and articles in peer-reviewed journals and 2) reports developed by interest groups, firms and public authorities. Additionally, the relevant actors and institutions in the four Nordic countries were identified.

Figure 2 Simplified model for a facilities management sectoral innovation system.

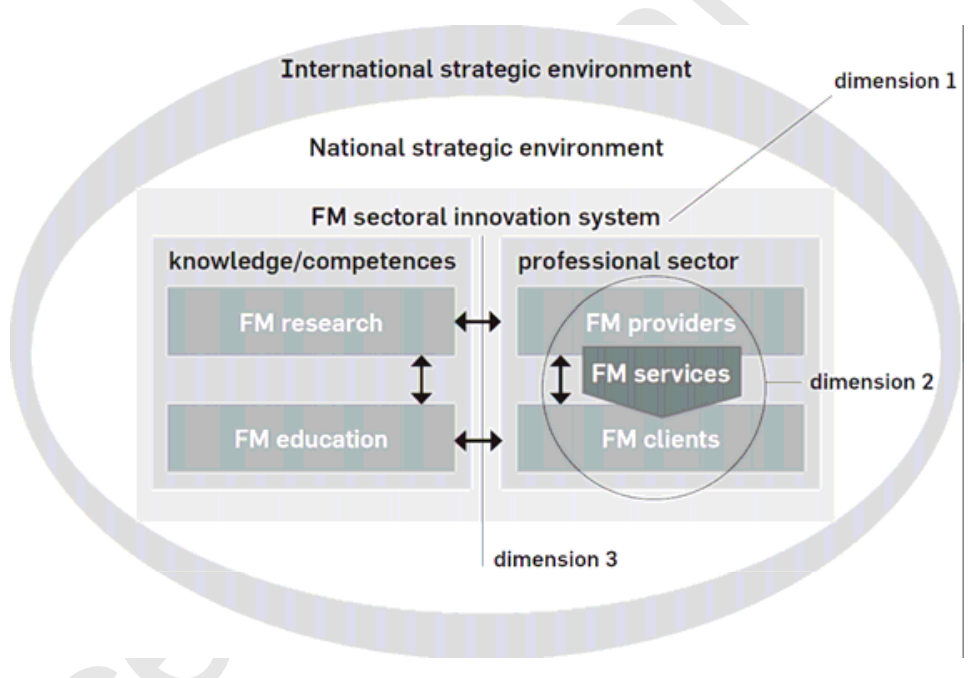

Finally, a described simple innovation systems model for the facilities management sector was developed. See Fig. 2. A similar model was developed in an early Dutch foresight project [61]. In the model used in this study, the facilities management sector is described as a number of producers (in-house and external) that supply facilities management services to their customers or clients. Public facilities management research and facilities management education and courses provide new (research-based) knowledge and professionals (graduates) in the sector. Furthermore, the model includes the national and international strategic environment around the facilities management sector and the affiliated research and education institutions. 


\subsection{Foresighting}

The foresighting sub-phase was structured as three overall dimensions that partially reflected the suggested distinction between innovation systems and their contexts as well as the innovation system approach's emphasis on the importance of knowledge and knowledge production.

The three dimensions provide, in three different ways, an indication and understanding of the flow and availability of knowledge and know-how. (See Fig. 1).

Dimension 1: Megatrends in the strategic environment that affect facilities management sectoral innovation system. This dimension addresses megatrends in the strategic environment of facilities management sector that are going to affect the sector in the long term (10 to 15 years). These megatrends can be characterised as external frame conditions and are considered to be beyond the influence of the actors within the facilities management sector. We distinguished between the national and international strategic environments. It is generally acknowledged in the literature that the concept of megatrends often is understood differently by different groups of respondents [62], [63], [64]. To ensure a common understanding of the concept among the participants in the four national workshops, all workshops were initiated with exactly the same presentation of the terminology and the concepts.

Dimension 2: Current trends and challenges for facilities management in each of the four countries. This dimension addresses trends within the facilities management sector in Denmark, Norway, Sweden, and Finland. A trend was defined as an inclination or a tendency that had been observed during the past two to five years and that was expected to prevail during the next two to five years. These internal trends are considered to be subject to influence by the actors within the facilities management sector or to be the results of strategic or managerial decisions made by facilities management actors in consideration of developments in the external environment. As mentioned above, all participants were carefully instructed in the differences between megatrends in the strategic environment of the facilities management sector and trends and challenges within the sector.

Dimension 3: Future need for new competences and new knowledge for facilities management professionals. This dimension addresses the need to generate new knowledge and build competence within the facilities management sector. The job profiles and key qualifications of facilities management professionals are of a general nature and are cross-functionally oriented. Accordingly, the profession uses knowledge and tools from a number of other professions and disciplines.

One national workshop was held in each of the four countries, Denmark, Norway, Sweden and Finland, between October 2010 and May 2011. The workshops were organised along the above-mentioned three dimensions and aimed to identify, evaluate and prioritise megatrends in the external environment, future trends and challenges inside the facilities management sector, and the needs for new competences and knowledge in facilities management in each of the four countries. For each dimension, the workshop participants were given a brief literature review as an introduction to the process. The participants were selected based on the innovation systems approach's emphasis on users and producers of both facilities management services and facilities management knowledge. The selection of participants strived for a balance between facilities management providers, customers and representatives from research and education. 
As a robustness check, the preliminary results were presented and discussed at a workshop held in affiliation with a Nordic facilities management conference in August 2011.

\subsection{Prioritising}

The aim of the prioritising sub-phase was twofold: to consolidate the results from the workshops and to prioritise issues. The method used was a Delphi-like questionnaire. The Delphi statements were developed through an iterative process that comprised three steps. The first step was a review survey of existing studies and foresight projects on the future of facilities management. This provided a rough overview of topics and issues of future relevance to the facilities management sector. The second step was to hold national workshops in Denmark, Norway, Sweden and Finland. As an iterative element, participants in the workshops discussed and refined the topics and issues from the desk study. As a third step, the preliminary results of the foresight process, including statements, were presented and discussed at a Nordic facilities management conference. To secure a high response rate, the number of individual statements was reduced to 40 and then clustered into the following six themes:

- Working life and style: 4 statements

- Resources and sustainability: 8 statements

- Technology: 6 statements

- FM competences: 5 statements

- Management and new services: 8 statements

- Value and professionalisation of FM: 9 statements.

To each statement, the respondents were invited to answer four questions that were derived from the objective of the foresight project:

- Importance of the development of FM (Very important, Important, Less important)

- Period in which the statement will be important for the FM sector (Short term, 2 to 5 years; Long term, 5 to 15 years; Never).

- Most important activities for supporting the development (one or more of the following: academic research, industrial $\mathrm{R} \& \mathrm{D}$, teaching, public regulation, dissemination of knowledge).

- Most important actors for promoting the development (one or more of the following: private clients - in-house FM; public clients - in-house FM; facility service providers; consulting companies; IT providers; construction companies; professional networks or associations).

A questionnaire was emailed to 117 experts who had previously participated in the national workshops and/or in the Nordic conference. Of the 117 experts, 51 replies were received, resulting in an overall response rate of $46 \%$. Twenty-seven out of the 51 responders worked in Denmark, 8 in Norway, 8 in Sweden, 6 in Finland and 2 in other countries. Because of the overrepresentation of Danish respondents, conclusions on national comparisons based only on the survey data were drawn with a great deal of caution. The respondents were also asked about their professional interests in facilities management. Twenty-five indicated that they were researchers, 9 were in-house FM clients, 5 were providers, 2 were teachers and 10 indicated other interests. All respondents were considered leading national experts in facilities management. 


\subsection{Other phases}

In the planning sub-phase, the project team analysed the results of the process and developed a proposal for a common Nordic research strategy.

Finally, a concluding report was prepared by the project team, and the results were disseminated to the target groups (the Nordic and European facilities management communities) through a variety of channels. The learning sub-phase included, among other elements, the present paper.

\section{Results of the Nordic facilities management foresight exercise}

The following section briefly discusses some of the results that are relevant for the scope of this paper.

\subsection{Megatrends in the strategic environment}

Despite some national differences, the megatrends assessed as having a very high impact in one country were not completely absent from the lists in the other countries, but they were ranked as less prominent. Thus, the big picture of this part of the foresight project left 9 megatrends across all four Nordic countries that were assessed for their impact on the facilities management sector within a time horizon of 10 to 15 years:

1. Societal and political focus on sustainability - increasingly more focus on environmental and clean energy issues

2. Mix of cultures - from homogenous to multicultural and multi-ethnic societies

3. Demographic changes - aging societies

4. New ways of working and living - from an immobile/stationary office to portable laptops or smart phones defining the workspace

5. Area and urban development - old industrial property mass reused for new purposes

6. Globalisation

7. Increasing cost pressure - from a focus on added value before 2008 to cost concerns after 2008 as a key factor of competitiveness in the facilities management sector

8. ICT, smart technologies and new materials

9. Changes in the public sector - political initiatives on outsourcing the large public facilities management sector in the Nordic countries (but with greater uncertainty in Norway)

However, the most significant megatrends were assessed differently at the workshops in the four countries. Increased focus on sustainability was ranked highest in Denmark and Norway but was ranked 4 in Finland. In contrast, sustainability was not among the most significant in Sweden, where it was ranked 9. Demographic changes with a labour shortage were ranked highest in Norway but ranked 4 in Denmark. ICT was ranked 2 in Norway and Sweden but was not ranked in Denmark or Finland. Globalisation was ranked 2 in Denmark and 4 in Sweden, but it was not ranked in Norway or Finland. National differences in assessing the importance and impact of megatrends are wellknown from other studies[63].

Two sets of megatrends were assessed as important across all four countries, however. The first concerned the increased focus on sustainability. The other set of megatrends concerned demographic changes, but the effect of this megatrend was interpreted or experienced differently in each country. 
These results support the main assumption of the innovation systems approach that context matters. We were able to determine a small number of cross-Nordic megatrends, but the differences, even among these four supposedly similar facilities management markets, are striking. Facilities management sectoral innovation systems are obviously subject to different national contexts.

\subsection{Current trends and challenges for the facilities management professional sector}

The workshops' assessments indicated three current trends and challenges for the facilities management professional sector that were shared by several countries. First, the challenge related to sustainability and energy was common to all four countries. Second, for Denmark, Sweden and Norway, issues related to standards, expectations management, and benchmarking could be considered aspects of the same trend. Third, workshop participants from both Norway and (especially) Sweden focused on issues related to costs and added value and the pressure to provide more service for lower cost.

Table 4. Most significant trends and challenges for the facilities management sector in four countries.

\begin{tabular}{|c|c|c|}
\hline Country & Short-term perspective & Long-term perspective \\
\hline Denmark & $\begin{array}{l}\text { Sustainability: energy, } \\
\text { environment, branding }\end{array}$ & $\begin{array}{l}\text { Sustainability: energy, environment, } \\
\text { branding }\end{array}$ \\
\hline Norway & $\begin{array}{l}\text { FM is not clearly defined. Develop } \\
\text { a common terminology. }\end{array}$ & Political development \\
\hline Sweden & $\begin{array}{l}\text { Technology and new ways to work } \\
\text { - meet needs }\end{array}$ & $\begin{array}{l}\text { How to balance the demand for } \\
\text { standardised services and deliver a } \\
\text { tailor-made FM operation with } \\
\text { international solutions at the same } \\
\text { time }\end{array}$ \\
\hline Finland & $\begin{array}{l}\text { Energy savings in FM (active } \\
\text { energy management, incentives for } \\
\text { service providers) }\end{array}$ & Housing FM \\
\hline
\end{tabular}

Again, in this dimension, the results differed among the four countries. Apart from the above-mentioned three issues, the assessment of the most significant trends and challenges, in both the short and long terms, varied between the four countries (see Table 4). In Denmark, sustainability in terms of energy, environment and branding was assessed to have the highest impact in both the short and long terms. For the other countries, the priorities between the short term and the long term were different.

\subsection{Needs for new knowledge and competences}

The discussion of the needs for new knowledge and competences had different results among the four workshops. For Denmark and Sweden, the highest priority was given to soft areas. In Denmark, this was to understand client needs, especially in development departments, and to transfer that understanding to the operational level, whereas in Sweden, social ability and personal competences were given the highest priority. For Norway and Finland, the highest priorities were more specific. For example, in Norway, consequences for facilities management regarding new ways of working and KPI (key performance indicators) were ranked highest (with the same ranking), whereas urban 
facilities management, e.g., development of areas with previously industrial properties, was ranked highest in Finland.

\subsection{A Delphi-like survey for prioritising}

As mentioned a number of times, there were significant differences between the viewpoints of the facilities management sectors in each of the four countries. There were national differences in what was considered the most important issue, measured as the percentages that indicated 'very important' on the questionnaire. Only two significant differences could be determined. First, the Finnish respondents assessed the theme 'Value and professionalisation of FM' to be less important than did the other respondents. Second, the Swedish respondents considered the theme 'FM competences' to be less important than did the other respondents.

Because the aim of the project was to formulate a common Nordic research strategy, individual statements were ranked according to a summation of the 'importance' and 'academic research' scores under the heading 'Most important activities to support development'. See Table 5.

The results further confirmed that two themes in particular might be of focus for a Nordic research strategy, namely, 'Value and professionalisation of FM' and 'Resources and sustainability'.

Because knowledge and the relationship between knowledge producers and knowledge users are important issues in the innovation system approach, we examine which actors were considered the most important for promoting each statement. It was observed that construction companies and professional networks and associations were assessed as playing a less dominant role except in the theme of 'Technology'. In particular, within this theme, facilities management networks and associations were assessed to play a role. Other differences were considered to be insignificant. 
Table 5. Top 10 statements derived from the combination of overall importance and the role of academic research.

\begin{tabular}{|c|c|c|}
\hline Rank & Theme & Statement \\
\hline 1 & $\begin{array}{l}\text { Value and } \\
\text { professionalisation of } \\
\text { FM }\end{array}$ & $\begin{array}{l}\text { 39. Introduction of methodologies for FM becoming a } \\
\text { critical strategic management tool linking the role of } \\
\text { facilities to the organisation's core business strategy }\end{array}$ \\
\hline 2 & $\begin{array}{l}\text { Resources and } \\
\text { sustainability }\end{array}$ & $\begin{array}{l}\text { 5. Introduction of methodologies for energy saving } \\
\text { management in FM services }\end{array}$ \\
\hline 3 & $\begin{array}{l}\text { Value and } \\
\text { professionalisation of } \\
\text { FM }\end{array}$ & $\begin{array}{l}\text { 32. Introduction of a set of principles for measurement } \\
\text { and documentation of the added value by FM services }\end{array}$ \\
\hline 4 & Technology & $\begin{array}{l}\text { 16. Development of cross disciplinary, life-cycle } \\
\text { oriented and holistic FM services for building } \\
\text { development, delivery and operation }\end{array}$ \\
\hline 5 & $\begin{array}{l}\text { Resources and } \\
\text { sustainability }\end{array}$ & $\begin{array}{l}\text { 8. Sustainability as a fundamental requirement in FM } \\
\text { services across most client groups }\end{array}$ \\
\hline 6 & $\begin{array}{l}\text { Value and } \\
\text { professionalisation of } \\
\text { FM }\end{array}$ & $\begin{array}{l}\text { 38. Introduction of methodologies for benchmarking of } \\
\text { FM services and standards across areas of applications }\end{array}$ \\
\hline 7 & $\begin{array}{l}\text { Value and } \\
\text { professionalisation of } \\
\text { FM }\end{array}$ & $\begin{array}{l}\text { 34. Introduction of FM services providing strategic } \\
\text { value for FM clients with continuously changing } \\
\text { functionality, technology and staff/customer demands }\end{array}$ \\
\hline 8 & $\begin{array}{l}\text { Value and } \\
\text { professionalisation of } \\
\text { FM }\end{array}$ & $\begin{array}{l}\text { 33. Introduction of a methodology to highlight and } \\
\text { ascertain return of investment for the organisation of } \\
\text { the FM costs spent in-house }\end{array}$ \\
\hline 9 & $\begin{array}{l}\text { Value and } \\
\text { professionalisation of } \\
\text { FM }\end{array}$ & $\begin{array}{l}\text { 35. Introduction of methodology for measurement of } \\
\text { performance against service level agreement (SLA) }\end{array}$ \\
\hline 10 & $\begin{array}{l}\text { Value and } \\
\text { professionalisation of } \\
\text { FM }\end{array}$ & $\begin{array}{l}\text { 36. Development of reliable key performance } \\
\text { indicators for FM services }\end{array}$ \\
\hline
\end{tabular}

\subsection{Implications for a common Nordic facilities management research agenda.}

When a common Nordic research agenda for facilities management is proposed, these national differences must be considered. Joint Nordic research must be relevant for all Nordic countries, or at least relevant for some of them. Based on this project, a common Nordic research agenda was proposed with two headings: a) valuation and professionalisation of facilities management and b) sustainability in facility management services. Research under the heading of value and professionalisation of facilities management could comprise issues such as facilities management methodologies as critical strategic management tools for linking the role of facilities to the organisation's core business strategy, principles for measuring and documenting the added value and returns on investment of facilities management services, and methodologies for measuring facilities management service performance against service-level agreements (SLAs), including benchmarking, reliable KPIs and standards across areas of applications. 
Research under the heading of sustainability in facility management services can consist of issues such as methodologies for managing energy savings in facilities management services and sustainability as a fundamental requirement in facilities management services across most client groups.

The survey indicates some differences between the four Nordic countries. One difference concerns the view of the role of academic research compared with the role of industry R\&D. To mitigate this potential area of conflicting interests, we suggest that a Nordic facilities management research agenda include close cooperation between researchers and industrial partners. Furthermore, the transfer of knowledge between researchers and practitioners must be an integral element of a Nordic facilities management research agenda.

The overall conclusions on a Nordic facilities management research agenda are in line with the European research agenda; research concerning evidence for value and sustainability reveals key priorities in a number of European strategy projects [65]. However, the Nordic study resulted in much more detailed and specific topics for future research within these themes.

\section{Conclusion and perspectives}

This paper departed from the observation that there seems to be a gap between innovation theory and foresight practice and that there is no specific framework available that combines both [7]. The paper demonstrates how elements from the innovation systems framework can contribute to the practice of strategic foresight. In the following, we will outline the most important conclusions of this paper.

First, this paper does not claim to present a full analysis of the interconnections between the innovation systems framework and the practice of strategic foresight; rather, we have focussed only on three elements of innovation system theory: innovation systems and context dependency, learning and user-producer interactions, and the role of knowledge and knowledge production. These elements are embodied in a simple sectoral innovation system model (including actors, knowledge flows and the strategic environment). See Fig. 2. Such models have been presented earlier, e.g., in Dutch foresight projects in the 1990s [61]. However, in our study, we developed this simple model further and utilised it more comprehensively.

Second, the innovation systems literature emphasises that innovation systems and sectors cannot always be analysed independent of their national or territorial contexts [38], [49]. This is mirrored in the foresight literature, which has shown that national cultures and traditions are determinants of perceptions of the future and of how decision making takes place [2], [66]. Although foresight projects eventually want to derive a result that is aggregated across several countries, we must design the foresight process so that differences in national contexts can be examined or so that important details are not blurred by averaging across national or regional contexts. Another implication of this context dependency is that prospective analyses must distinguish between the analysis's focus area (in our case, the facilities management sector) and the sector's context. In our study, we distinguished clearly between future trends in the external environments (context) of the sector and trends and challenges within the sector. Many foresight exercises only analyse 'the future' of a sector or an industry and do not take into account what can be affected by mutual efforts within the sector (e.g., standards, energy 
consumption, managerial practice) and what cannot be affected by the sector (e.g., climate changes, migration, globalisation).

Third, learning and user-producer interactions are concerns of the innovation system literature [50]-[52]. In particular, the conception that innovation emerges from a confrontation of user needs with opportunities is important [52]. The implication of this for the practice of sector foresight is that when the sector is mapped, its upstream and downstream value chains must be considered and both user and producers must be included in the process. A joint analysis and collaborative effort to prepare for the future might benefit all actors within a sector, hence the newer foresight literature's focus on mobilising joint actions as a core part of modern definitions of foresight [67]. In this paper, we applied a simple model, but more complex models might prove to be more useful. We included both users and producers of knowledge (dimension 3 in Fig. 2) and users and producers of facilities management services (dimension 2 in Fig. 2).

Fourth, because knowledge and knowledge production are also core concepts of innovation systems, the flow of knowledge between a sector's knowledge producers and knowledge users, as well as the future needs for knowledge and competences, must be included in foresight projects. Although this is generally acknowledged in the foresight literature [11], foresight exercises often do not include the demand for knowledge, the existing competences, and the realities and wishes of firms [17]. Departing from the innovation systems literature, we have suggested a simple model and a simple approach that can provide input on the demand for knowledge and firms' realities and wishes (dimension 3 in Fig. 2). We have actively facilitated a discussion between users and producers of knowledge on the future needs for new knowledge and new competences, and this discussion followed from prior analysis and discussion of megatrends in the external environment and of trends and challenges within the facilities management sector.

The approach presented in this paper has been proven to be useful in other foresight exercises (e.g., sensor technology and nanotechnology with sectoral elements included) that were conducted by the authors of this paper [68], [69]. This, to some extent, indicates that the approach can be extended to other sectors or to foresight in general. However, as stated often in the practical foresight literature, there is no such thing as a one-size-fits-all approach in foresight. Additionally, although we have suggested a simple model and a simple approach, more advanced approaches might prove more useful.

As argued in the introduction, the interconnection between foresight and innovation systems has been tentatively explored by other authors, but they have mainly focused on how foresight can contribute to innovation system analysis [18]-[20]. Other studies have analysed the effect of foresight on innovation policy making [21]. With this paper, we give an initial example of how the innovation systems framework can contribute concepts and simple models to the practice of foresight. We expect that more research on this issue will be useful. Furthermore, we indicated in the introduction that there is little communication between innovation systems research and the practice of and research in strategic foresight and that the linkages between them remain embryonic and underdeveloped in the academic literature. Thus, there seems to be much future research potential in this area as well. 


\section{References}

[1] L. Georghiou, J. Cassingena Harper, M. Keenan, I. Miles, and R. Popper, The Handbook of Technology Foresight. Cheltenham, UK: Edward Elgar Publishing, 2008

[2] M. Keenan and R. Popper, "Comparing foresight 'style' in six world regions," Foresight, vol. 10, no. 6, pp. 16-38, 2008.

[3] J. Calof and J. E. Smith, "Critical success factors for government-led foresight," Sci. Public Policy, vol. 37, no. 1, pp. 31-40, Feb. 2010.

[4] C. Daheim and G. Uerz, "Corporate foresight in Europe: from trend based logics to open foresight," Technol. Anal. Strateg. Manag., vol. 20, no. 3, pp. 321-336, May 2008.

[5] R. Rohrbeck and H. G. Gemünden, "Corporate foresight: Its three roles in enhancing the innovation capacity of a firm," Technol. Forecast. Soc. Change, vol. 78, no. 2, pp. 231-243, Feb. 2011.

[6] L. A. Costanzo and R. B. MacKay, Handbook of Research on Strategy and Foresight. Edward Elgar, Cheltenham, UK. Northhamton, MA, USA, 2010.

[7] M. Weber, P. Schaper-Rinkel, and M. Butter, "Sectoral Innovation Foresight. Introduction / Interim Report,” Brussels, 2009.

[8] B. Dachs and M. Weber, "Sectoral Innovation Foresight Textiles and Clothing Sector," Europe INNOVA, www.europe-innova.eu/web/guest/sectoralinnovation-watch/publications-tools, 2010.

[9] F. Abadie, M. Friedewald, and K. M. Weber, "Adaptive foresight in the creative content industries: anticipating value chain transformations and ned for policy action," Sci. Public Policy, vol. 37, no. 1, pp. 19-30, 2010.

[10] L. Georghiou and M. Keenan, "Evaluation of national foresight activities: Assessing rationale, process and impact," Technol. Forecast. Soc. Change, vol. 73, no. 7, pp. 761-777, Sep. 2006.

[11] I. Miles, J. C. Harper, L. Georghiou, M. Keenan, and R. Popper, "The Many Faces of Foresight," in Handbook of Technology Foresight, Cheltenham, UK: Edward Elgar Publishing, 2008.

[12] R. Barré and M. Keenan, "Revisiting Foresight Rationales: What Lessons from the Social Sciences and Humanities?," in Future-Oriented Technology Analysis strategic Intelligence for an Innovative Economy, C. Cagnin, M. Keenan, R. Johnston, F. Scapolo, and R. Barré, Eds. Springer, 2008.

[13] É. Hideg, "Theory and practice in the field of foresight," Foresight, vol. 9, no. 6, pp. 36-46, 2007.

[14] T. Fuller and K. Loogma, "Constructing futures: A social constructionist perspective on foresight methodology," Futures, vol. 41, no. 2, pp. 71-79, Mar. 2009. 
[15] M. A. Öner, "On theory building in Foresight and Futures Studies: A discussion note," Futures, vol. 42, no. 9, pp. 1019-1030, Nov. 2010.

[16] L. Georghiou and M. Keenan, "Evaluation of national foresight activities: Assessing rationale, process and impact," Technol. Forecast. Soc. Change, vol. 73, no. 7, pp. 761-777, Sep. 2006.

[17] R. Smits, S. Kuhlmann, and P. Shapira, The Theory and Practice of Innovation Policy: An International Research Handbook. Edward Elgar, 2010.

[18] B. R. Martin and R. Johnston, "Technology foresight for wiring up the national innovation system: experiences in Britain, Australia, and New Zealand," Technol. Forecast. Soc. Change, vol. 60, no. 1, pp. 37-54, Jan. 1999.

[19] F. Alkemade, C. Kleinschmidt, and M. Hekkert, "Analysing emerging innovation systems: a functions approach to foresight," Int. J. Foresight Innov. Policy, vol. 3, no. 2, pp. 139-168, 2007.

[20] C. Cagnin, E. Amanatidou, and M. Keenan, "Orienting European innovation systems towards grand challenges and the roles that FTA can play," Sci. Public Policy, vol. 39, no. 2, pp. 140-152, Apr. 2012.

[21] A. Havas, D. Schartinger, and M. Weber, "The impact of foresight on innovation policy-making: recent experiences and future perspectives," Res. Eval., vol. 19, no. 2, pp. 91-104, Jun. 2010.

[22] O. Saritas, "Systemic foresight methodology," in Forth International Seville Conference on Future-Oriented Technology Analysis (FTA) FTA and Grand Societal Challenges - Shaping and Driving Structural and Systemic Transformations SEVILLE, 12-13 MAY 2011, 2011.

[23] R. W. Grimshaw, "FM: the professional interface," Facilities, vol. 21, no. 3/4, pp. 50-57, 2003.

[24] B. Nutt, "Infrastructure resources: forging alignments between supply and demand," Facilities, vol. 22, no. 13/14, pp. 335-343, 2004.

[25] P. Roberts, "FM: new urban and community alignments," Facilities, vol. 22, no. 13/14, pp. 349-352, 2004.

[26] R. Saurin, J. Ratcliffe, and M. Puybaraud, "Tomorrow's workplace: a futures approach using prospective through scenarios," J. Corp. Real Estate, vol. 10, no. 4, pp. 243-261, 2008.

[27] J. M. Wiggins, "Training tomorrow's facilities managers," Facil. Manag., no. February, pp. 22-24, 2006.

[28] M. Toivonen, "Foresight in Services : Possibilities and Special Challenges," Serv. Ind. J., vol. 24, no. 1, pp. 79-98, 2004.

[29] IFMA, “Current Trends and Future Outlook for Facility Management," Houston, TX, 2005. 
[30] IFMA, "Exploring the Current Trends and Future Outlook for Facility Management Professionals," Houston, TX, 2007.

[31] Chartered Management Institute, "Environmental scanning Trends Affecting the World of Work in 2018 Executive summary," London, 2008.

[32] K. Balmer and B. Clarke, "Facilities Management Trends," 2010. [Online]. Available: http://foresight-trendscan.blogspot.dk/2009/10/facility-managementtrends.html.

[33] ISS, "ISS 2020 Vision. Scenarios for the future of the Global Facility Management Industry," Copenhagen, 2011.

[34] M. Cariola and S. Rolfo, "Evolution in the rationales of foresight in Europe," Futures, vol. 36, no. 10, pp. 1063-1075, Dec. 2004.

[35] R. Barré, "Foresight and their themes: analysis, typology and perspectives," in The role of foresight in the selection of research policy priorities, 2002.

[36] A. Schoen, T. Könnölä, P. Warnke, R. Barré, and S. Kuhlmann, "Tailoring Foresight to field specificities," Futures, vol. 43, no. 3, pp. 232-242, Apr. 2011.

[37] A. D. Andersen and P. D. Andersen, "Innovation System Foresight", in review for Technol. Forecast. Soc. Change.

[38] R. Nelson and N. Rosenberg, "Technical Innovation and National Systems," in National Innovation Systems - A Comparative Analysis, R. R. Nelson, Ed. Oxford University Press, USA, 1993.

[39] B.-Å. Lundvall, National Systems of Innovation - Toward a Theory of Innovation and Interactive Learning. London: Pinter, 1992.

[40] C. Freeman, Technology policy and economic performance: Lessons from Japan. London: Pinter, 1987.

[41] P. Cooke, M. G. Uranga, and G. Etxebarria, "Regional innovation systems: Institutional and organisational dimensions," Res. Policy, vol. 26, pp. 475-491, 1997.

[42] B. T. Asheim and M. Gertler, "The geography of innovation: regional innovation systems," in The Oxford handbook of innovation, J. Fagerberg, D. Mowery, and R. Nelson., Eds. Oxford University Press, USA, 2005.

[43] F. Malerba, "Sectoral systems of innovation and production," Res. Policy, vol. 31, no. 2, pp. 247-264, Feb. 2002.

[44] F. Malerba, "Sectoral systems: how and why innovation differes across sectors," in The Oxford handbook of innovation, J. Fagerberg, D. Mowery, and R. Nelson, Eds. Oxford University Press, USA., 2005.

[45] A. Bergek, M. Hekkert, and S. Jacobsson, "Functions in innovation systems: A framework for analysing energy system dynamics and identifying goals for 
system-building activities by entrepreneurs and policy makers," Innov. a low carbon Econ. Econ. institutional Manag. approaches, p. 79, 2008.

[46] B. Carlsson and R. Stankiewitz, Technological systems and economic performance: the case of factory automation. Dordrecht: Kluwer Academic Publishers, 1995.

[47] W. B. Arthur, S. Durlauf, and D. Lane, "Introduction," in The Economy as an Evolving Complex System II, W. B. Arthur, S. Durlauf, and D. Lane, Eds. Reading, Massachusetts: Addison-Wesley, 1997.

[48] G. Dosi, "Sources, procedures, and microeconomic effects of innovation," J. Econ. Lit., vol. 26, no. 3, pp. 1120-1171, 1988.

[49] K. Pavitt, "Sectoral patterns of technical change: Towards a taxonomy and a theory," Res. Policy, vol. 13, no. 6, pp. 343-373, Dec. 1984.

[50] B. Johnson, "Institutional Learning," in National Systems of Innovation - Toward a Theory of Innovation and Interactive Learning, B. A. Lundvall, Ed. London: Pinter, 1992.

[51] B. Nooteboom, "Learning by Interaction: Absorptive Capacity, Cognitive Distance and Governance," J. Manage., vol. 4, pp. 69-92, 2000.

[52] B.-Å. Lundvall, Product Innovation and User-Producer Interaction, Industrial., no. 31. Aalborg: Aalborg University Press, 1985, p. 39.

[53] C. Freeman, "The greening of technology and models of innovation," Technol. Forecast. Soc. Change, vol. 53, no. 1, pp. 27-39, Sep. 1996.

[54] A. Alsan and M. A. Oner, “An integrated view of foresight: integrated foresight management model," Foresight, vol. 5, no. 2, pp. 33-45, 2003.

[55] CEN, "EN 15221-1: 2006 Facility Management - Part 1 : Terms and definitions." CEN (European Comittee for Standardization), Brussels, 2006.

[56] "Facility Management - Part 1: Terms and definitions." European Committee for Standardization, CEN TC 348, p. 32, 2008.

[57] S. A. Teichmann, "FM Market Size in Europe,” Eur. FM Insight, vol. 11, pp. 57, 2009.

[58] P. A. Jensen, K. Nielsen, and S. B. Nielsen, Facilities Managment Best Practice in the Nordic Countries - 36 cases. Centre for Facilities Management - Realdania Research, 2008.

[59] P. A. Jensen, The Market for Facilities Management in the Nordic Countries. Lyngby: Centre for Facilities Management - Realdania Research, 2011.

[60] P. D. Andersen and B. Rasmussen, Fremsyn: Metoder, praksis og erfaringer. Danish Agency for Science, Technology and Innovation, Ministry of Science, Innovation and Higher Education, 2012. 
[61] RAND, “Technology Radar. Methodology,” The Hague, NL, 1998.

[62] A. Slaughter, "Looking for the real 'megatrends,"” Futures, vol. 3052, no. October 1993, 2000.

[63] M. Atilla Oner, A. N. Basoglu, and M. S. Kok, "Megatrends as perceived in Turkey in comparison to Austria and Germany," Technol. Forecast. Soc. Change, vol. 74, no. 4, pp. 538-557, May 2007.

[64] V. von Groddeck and J. O. Schwarz, "Perceiving megatrends as empty signifiers: A discourse-theoretical interpretation of trend management," Futures, vol. 47, pp. 28-37, Mar. 2013.

[65] P. A. Jensen, P. D. Andersen, and B. Rasmussen, "Future research agenda for FM in the Nordic countries in Europe," Facilities, vol. 32, no. 1, pp. 4-17, 2014.

[66] P. D. Andersen and L. B. Rasmussen, "The impact of national traditions and cultures on national foresight processes," Futures, Jan. 2014.

[67] I. Miles, J. C. Harper, L. Georghiou, M. Keenan, and R. Popper, "The Many Faces of Foresight," in Handbook of Technology Foresight, .

[68] P. D. Andersen, B. H. Jørgensen, L. Lading, and B. Rasmussen, "Sensor foresight-technology and market," Technovation, vol. 24, no. 4, pp. 311-320, Apr. 2004.

[69] P. D. Andersen, B. Rasmussen, M. Strange, and J. Haisler, "Technology foresight on Danish nano-science and nano-technology," Foresight, vol. 7, no. 6, pp. 64 $78,2005$. 